\title{
PENGARUH MODAL SOSIAL KOGNITIF TERHADAP PERFORMANSI DUSUNG
}

\section{THE INFLUENCE of COGNITIVE SOCIAL CAPITAL ON THE PERFORMANCE OF DUSUNG \\ Oleh}

Anjely A. Parera ${ }^{*}$, Agustinus Kastanya ${ }^{2}, \&$ Marthina Tjoa ${ }^{3}$

${ }^{1}$ Mahasiswa Prodi Manajemen Hutan Program Pascasarjana Universitas Pattimura, Ambon

${ }^{2,3}$ Dosen Prodi Manajemen Hutan Program Pascasarjana Universitas Pattimura, Ambon, 97233

Email : pareraanjely@gmail.com

\begin{tabular}{|l|l}
\hline Diterima: 28 Maret 2020 & Disetujui: 25 Mei 2020
\end{tabular}

\begin{abstract}
Abstrak
Modal sosial kognitif masyarakat desa Murnaten dalam pengelolaan dusung meliputi kepercayaan, kerjasama, dan solidaritas yang didasari oleh norma, nilai, sikap, dan keyakinan berorientasi dalam bentuk tindakan sehingga menguatkan upaya-upaya positif dalam pengelolaan dusung. Penelitian ini bertujuan untuk menganalisis pengaruh modal sosial kognitif terhadap performansi dusung di Desa Murnaten Kecamatan Taniwel Kabupaten Seram bagian Barat. Hasil penelitian menunjukkan bahwa pengaruh modal sosial kognitif (kepercayaan, kerjasama dan solidaritas) terhadap performansi dusung (produktivitas, efisiensi, keberlanjutan dan keadilan dengan nilai kofisien determinansi adjusted $\mathrm{R}^{2}$ sebesar 0,771 , dengan F-hitung $(25,359)>$ F-tabel $(2,759)$, dan uji parsial t-hitung $>\mathrm{t}$-tabel $(2,059)$ menunjukkan bahwa modal sosial kognitif (kepercayaan, kerjasama dan solidaritas) memiliki pengaruh signifikan secara simultan dan parsial terhadap performansi dusung (produktivitas, efisiensi, keberlanjutan dan keadilan) pada taraf kepercayaan 0,01 dan 0,05.
\end{abstract}

Kata kunci : modal sosial kognitif, performansi, dusung

\begin{abstract}
The cognitive social capital of the Murnaten village community in managing dusung includes trust, cooperation, and solidarity-based on norms, values, attitudes, and oriented beliefs in the form of action to strengthen positive efforts in dusung management. This study aims to analyze the effect of cognitive, social capital on the performance of dusung in Murnaten Village, Taniwel District, West Seram Regency. The results showed that the effect of cognitive, social capital (trust, cooperation, and solidarity) on dusung performance (productivity, efficiency, sustainability and fairness with a determinant coefficient value adjusted R2 of 0.771 , with Fcount (25.359)> F-table (2.759), and the partial test t-count> t-table (2.059) shows that cognitive, social capital (trust, cooperation, and solidarity) has a significant effect simultaneously and partially on dusung performance (productivity, efficiency, sustainability, and justice) at the 0.01 level of confidence. and 0.05.fairness) at the 0.01 and 0.05 confidence levels.
\end{abstract}

Keywords : the cognitive social capital, performance, Dusung

DOI: $10.30598 /$ jhppk.2020.4.2.150

ISSN ONLINE: 2621-8798 


\section{PENDAHULUAN}

Modal sosial merupakan sumberdaya aktual dan potensial yang dimiliki oleh individu dan/atau anggota dalam kelompok sosial yang berasal dari jaringan sosial dengan kelembagaan yang berlangsung terus menerus dalam bentuk pengakuan dan perkenalan timbal balik kepada anggotanya sebagi bentuk dukungan kolektif (Suhardjito dan Saputro, 2008). Hal tersebut menekankan pentingnya transformasi dari hubungan sosial seperti pertetanggaan, pertemanan, atau kekeluargaan, menjadi hubungan yang bersifat jangka panjang yang diwarnai oleh perasaan kewajiban terhadap orang lain. Modal sosial menurut Bourdieu (1970) juga menegaskan tentang sesuatu yang berhubungan satu dengan yang lain, baik ekonomi, budaya, maupun bentukbentuk modal sosial (social capital) berupa institusi lokal maupun kekayaan sumberdaya alam lainnya. Pendapat ini menegaskan tentang modal sosial yang mengacu pada keuntungan dan kesempatan yang didapatkan seseorang didalam masyarakat melalui keanggotaannya dalam entitas sosial tertentu seperti paguyuban, kelompok arisan, atau asosiasi tertentu (Damsar 2009). James Coleman (1988), mendefinisikan modal sosial berdasarkan fungsinya, yaitu modal sosial sebagai varian entitas yang terdiri dari beberapa struktur sosial yang memfasilitasi tindakan dari para pelakunya, apakah dalam bentuk individu atau kelompok/organisasi dalam suatu struktur sosial.

Modal sosial adalah aspek-aspek dari struktur hubungan antara individu-individu yang memungkinkan mereka menciptakan nilai-nilai baru. Lebih lanjut ia menjelaskan bahwa modal sosial sebagai sesuatu yang memiliki dua ciri, yaitu merupakan aspek dari struktur sosial serta memfasilitasi tindakan individu dalam struktur sosial. Dalam pengertian ini, bentuk-bentuk modal sosial berupa kewajiban dan harapan, potensi informasi, norma dan sanksi yang efektif, hubungan otoritas, serta organisasi sosial yang bisa digunakan secara tepat dan melahirkan kontrak sosial. Modal sosial dapat didefinisikan pengertian modal sosial sebagai "simpati atau rasa kewajiban yang dimiliki seseorang atau kelompok terhadap orang lain atau kelompok lain yang mungkin dapat menghasilkan potensi keuntungan dan tindakan preferensial, dimana potensi dan preferensial itu tidak bisa muncul dalam hubungan sosial yang bersifat egois" (Suharjito dkk, 2002).

Menurut Ostrom (1992), modal sosial adalah kemampuan suatu komunitas merajut institusi atau pranata. Lebih lanjut Ostrom menjelaskan bahwa melalui serangkaian pengalamannya yang cukup luas dalam mengkaji proyek-proyek pembangunan di negara-negara berkembang menyatakan bahwa modal sosial merupakan prasyarat bagi keberhasilan suatu proyek pembangunan.

Ostrom menitikberatkan pada rajutan institusi atau pranata. Dalam hal ini yang dimaksud dengan institusi atau pranata adalah seperangkat aturan yang digunakan secara aktual oleh sekelompok individu atau komunitas untuk mengorganisasikan tindakan yang berulangulang yang menghasilkan suatu luaran yang mempengaruhi kelompok individu tersebut dan juga sangat potensial untuk mempengaruhi orang lain. Kesimpulannya, institusi adalah seperangkat aturan yang berlaku atau digunakan dan dijadikan sebagai acuan berperilaku. Rumusan konsep modal sosial menurut Putnam, Leonardi dan Nonetti (1993), adalah bahwa modal sosial mengacu pada aspek-aspek utama dari organisasi sosial 
seperti kepercayaan, norma-norma, dan jaringan-jaringan yang dapat meningkatkan efisiensi dalam suatu masyarakat melalui fasilitasi bagi tindakan-tindakan yang terkoordinasi. Modal sosial senantiasa berada pada posisi utama dalam membangun dan terciptanya masyarakat sipil. Sebagai elemen penting yang terkandung dalam masyarakat sipil, modal sosial menunjuk pada nilai dan norma yang dipercayai dan dijalankan oleh sebagian besar anggota masyarakat dalam kehidupan sehari-hari, yang secara langsung maupun tidak langsung mempengaruhi kualitas hidup individu dan keberlangsungan komunitas masyarakat.

Teknik-teknik penanaman dalam sistem agroforestri di pulau Ambon, pulau Seram, dan pulau-pulau Lease Provinsi Maluku, merupakan tradisi pengelolaan hutan yang dikenal masyarakat dengan istilah dusung. Dusung adalah sebuah istilah yang biasanya digunakan masyarakat Maluku dalam pengelolaan sumberdaya hutan dengan teknik penanaman, komoditas tanaman yang bervariasi, sehingga memiliki tingkat keanekaragaman (biodiversity) yang tinggi (Ajawaila 1996). Dusung merupakan bentuk pemanfaatan lahan (land uses) secara optimal dalam suatu hamparan yang menggunakan produksi biologi berdaur pendek (annual) dan berdaur panjang (perennial) atau kombinasi tanaman kehutanan, perkebunan dan pertanian yang berdasarkan asas kelestarian dan keberlanjutan hasil (Sustainability).

Dusung secara holistik dapat diartikan sebagai suatu usaha penanaman secara bersama dan berurutan antara tanaman kehutanan, perkebunan dan tanaman , efisiensi, keberlanjutan dan keadilan).

\section{METODE PENELITIAN}

Penelitian dilakukan pada Desa Murnaten Kecamatan Taniwel Kabupaten pertanian, yang tentunya didasarkan pada kondisi fisik wilayah (local site) dan budaya (culture) masyarakat. Pengembangan pola dusung di Maluku, dimaksudkan untuk meningkatkan produktivitas (Enchanced productivity), pemberdayaan masyarakat (human well-being) dan pengendalian dampak lingkungan (environmental impacts). Dusung merupakan salah satu bentuk pemanfaatan lahan hutan bagi masyarakat dalam upaya untuk memenuhi kebutuhan hidup masyarakat. Tradisi mengelola dusung oleh masyarakat sudah berlangsung turun temurun. Hal ini sejalan dengan yang dikemukakan oleh Silaya (2003) bahwa dusung telah dikenal oleh masyarakat Pulau Seram sejak nenek moyang mereka. Istilah dusung pada jenis-jenis sumberdaya alam tertentu seperti dusung sagu, dusung damar dan dusung meranti yang merupakan warisan masa lalu. Dalam perkembangan istilah dusung ini digunakan pada lahan yang berkaitan dengan kepemilikan dan penggunaannya seperti dusung negeri, dusung dati, dusung pusaka, dusung raja, dan sebagai. Istilah dusung ini juga digunakan pada lahan yang berkaitan dengan jenis tanaman dominan yang tumbuh dan/atau diusahakan diatas lahan dusung kelapa (lahan yang didominasi oleh tanaman kelapa), dusung cengkih (lahan didominasi oleh tanaman cengkih), dan juga hutan alam atau ewang. Berdasarkan uraian diatas, penelitian ini bertujuan untuk menganalisis pengaruh modal sosial kognitif (kepercayaan, kerjasama, dan solidaritas) terhadap performansi dusung (produktivitas

Seram Bagian barat dan berlangsung bulan Agustus s.d Desember 2018. Penelitian ini menggunakan metode survey. Pengumpulan 
data dan informasi dilakukan dengan teknik wawancara menggunakan kuesioner terstruktur kepada responden (Irawan, 2007; Singaribun dan effendi 2008). Selain wawancara dengan kuesioner terstruktur, juga dilakukan wawancara mendalam dengan kuesioner semi terstruktur kepada responden yang dianggap lebih mengetahui informasi yang diperlukan sesuai fokus data. Wawancara mendalam dilakukan kepada perangkat desa dan beberapa tokoh masyarakat. Hal ini dilakukan guna melengkapi data wawancara anggota masyarakat.

Data primer yang digunakan berupa kondisi umum lokasi penelitian, modal social masyarakat dalam pengelolaan dusung,

Selang nilai $=$ total skor tertinggi - total skor terendah Jumlah kelas

Jumlah kelas menggunakan 3 kelas (rendah, sedang, tinggi) dengan jumlah responden $10 \quad \%$ dari jumlah pemilik/pengelola dusung. Nilai untuk setiap performansi dusung (produktivitas dusung, sustainabilitas/keberlanjutan dusung, ekuitabilitas/keadilan, dan efisiensi). Sedangkan data sekunder berupa studi literature dan data-data laporan (dokumen) dari berbagai sumber serta instansi terkait untuk mendukung penelitian ini. Untuk menentukan responden dilakukan secara acak (random sampling), dan dipilih sebanyak 30 orang dari total jumlah pemilik/pengelola dusung yang ada pada desa Murnaten.

Pengukuran Tingkat Modal Sosial

Besaran tingkat modal sosial (rendah, sedang, tinggi) dalam mendukung pengelolaan dusung menggunakan persamaan (1).

pertanyaan pada responden adalah yang terendah (1), sedang (2), dan yang tertinggi (3). Cara pengukuran tingkat modal sosial seca rinci disajikan pada Tabel 1.

Tabel 1. Cara pengukuran tingkat modal sosial kognitif

\begin{tabular}{|c|c|c|c|c|c|c|c|c|}
\hline \multirow[t]{3}{*}{ No } & \multirow[b]{3}{*}{$\begin{array}{l}\text { Modal } \\
\text { Sosial }\end{array}$} & \multirow{3}{*}{$\begin{array}{c}\text { Jumlah } \\
\text { Pertan } \\
\text { yaan }\end{array}$} & \multirow{2}{*}{\multicolumn{2}{|c|}{ Jawaban Responden }} & \multirow{3}{*}{$\begin{array}{c}\text { Total Nilai }(10 \% \\
\text { Responden) }\end{array}$} & \multirow{3}{*}{$\begin{array}{l}\text { Selang } \\
\text { Kelas }\end{array}$} & \multirow{2}{*}{\multicolumn{2}{|c|}{$\begin{array}{c}\text { Tingkat Modal Sosial } \\
\text { Masyarakat }\end{array}$}} \\
\hline & & & & & & & & \\
\hline & & & Kriteria & Nilai & & & Kelas & $\begin{array}{l}\text { Ukuran } \\
\text { (Total } \\
\text { Nilai) }\end{array}$ \\
\hline \multirow[t]{3}{*}{1.} & Kepercayaan & 7 & Tidak percaya & 1 & $(30 * 7 * 1) \mathrm{s} / \mathrm{d}$ & (630- & Renda & $210-350$ \\
\hline & & contoh & Ragu-ragu & 2 & $(30 * 7 * 3)$ & $210) / 3$ & $\mathrm{~h}$ & $351-490$ \\
\hline & & & Percaya & 3 & $210 \mathrm{~s} / \mathrm{d} 630$ & $=140$ & $\begin{array}{l}\text { Sedang } \\
\text { Tinggi }\end{array}$ & $491-630$ \\
\hline \multirow[t]{3}{*}{2.} & Kerjasama & 2 & Tidak Pernah & 1 & $(30 * 2 * 1) \mathrm{s} / \mathrm{d}$ & $(180-60) / 3$ & Renda & $60-100$ \\
\hline & & & Jarang & 2 & $(30 * 2 * 3)$ & $=40$ & & $101-140$ \\
\hline & & & Sering/Selalu & 3 & $60 \mathrm{~s} / \mathrm{d} 180$ & & $\begin{array}{l}\text { Sedang } \\
\text { Tinggi }\end{array}$ & $141-180$ \\
\hline \multirow[t]{3}{*}{3.} & Solidaritas & 3 & Tidak Pernah & 1 & $(30 * 3 * 1) \mathrm{s} / \mathrm{d}$ & $(270-90) / 3$ & Renda & $90-150$ \\
\hline & & & Jarang & 2 & $(30 * 3 * 3)$ & $=60$ & & $151-210$ \\
\hline & & & Sering/Selalu & 3 & $90 \mathrm{~s} / \mathrm{d} 270$ & & $\begin{array}{l}\text { Sedang } \\
\text { Tinggi }\end{array}$ & $211-270$ \\
\hline \multirow[t]{3}{*}{$\mathrm{I}$} & Kognitif & $7+2+3$ & & & $(30 * 12 * 1) \mathrm{s} / \mathrm{d}$ & $(1080-$ & Renda & $360-600$ \\
\hline & & $=12$ & & & $(30 * 12 * 3)$ & $360) / 3$ & & $601-840$ \\
\hline & & & & & 360 s/d 1080 & $=240$ & $\begin{array}{l}\text { Sedang } \\
\text { Tinggi }\end{array}$ & $841-1080$ \\
\hline
\end{tabular}


Pengukuran Performansi dusung

Parameter performansi dusung dijelaskan berdasarkan produktivitas dusung, keberlanjutan dusung (sustainabilitas), keadilan (equitabilitas) dan efisiensi.

\section{Produktivitas Dusung.}

Produktivitas dusung adalah keluaran (output) produk yang bernilai dari dusung, dalam konteks ini keluaran (output) produk dusung diukur dari nilai/pendapatan hasil yang diperoleh dusung pertahun, yaitu:

- Produktivitas Rendah : Nilai hasil dusung/tahun < Rp. 15 juta.

- Produktivitas Sedang : Nilai hasil dusung/tahun Rp. 15 juta s/d Rp. 25 juta.

- Produktivitas Tinggi : Nilai hasil dusung/tahun > Rp 25 juta.

\section{Sustainabilitas (Keberlanjutan) Dusung}

Sustainabilitas (keberlanjutan) dusung adalah kemampuan dusung untuk menjaga produktivitas dari waktu ke waktu, yang diukur berdasarkan usaha usaha yang dilakukan untuk mempertahankan keberadaan tanaman (persemaian/pembibitan, replanting/ peremajaan dan pemeliharaan tanaman), yaitu :

- Rendah : Tidak pernah dilakukan

- Sedang : Jarang (Kadang-kadang) dilakukan

- Tinggi : Sering dilakukan

3. Equitabilitas (Keadilan)
Equitabilitas (keadilan) adalah pemerataan distribusi manfaat dari keberadaan dusung, yang diukur dari tingkat akses terhadap manfaat yang dirasakan oleh masyarakat.

- Rendah : Hanya bermanfaat bagi pemiliknya saja

- Sedang : Bermanfaat bagi pemiliknya dan para pembeli buahnya

- Tinggi : Bermanfaat bagi banyak pihak (pemilik, masyarakat sebagai tenaga kerja/mitra, sanak famili dan tetangga yg tidak memiliki dusung, serta para pembeli buahnya, dll).

\section{Efisiensi}

Efisiensi adalah penghematan (minimalisasi) biaya dalam proses pengelolaan dusung hingga menghasilkan produk, diukur dari tingkat efisiensi biaya produksi:

- Efisiensi Rendah : Biaya produksi > 10\% dari Nilai Produksi

- Efisiensi Sedang : Biaya produksi 5\% 10\% dari Nilai Produksi

- Efisiensi Tinggi : Biaya produksi $<5 \%$ dari Nilai Produksi.

Secara rinci cara pengukuran tingkat performansi dusung dapat dilihat pada Tabel 2.

Tabel 2. Cara pengukuran tingkat performansi dusung

\begin{tabular}{|c|c|c|c|c|c|c|c|c|}
\hline \multirow[t]{2}{*}{ No } & & \multirow[t]{2}{*}{ Parameter } & \multicolumn{2}{|c|}{$\begin{array}{c}\text { Jawaban } \\
\text { Responden }\end{array}$} & \multirow{2}{*}{$\begin{array}{c}\text { Total Nilai } \\
\text { Komunitas } \\
\text { (30 Responden) }\end{array}$} & \multirow{2}{*}{$\begin{array}{l}\text { Selang } \\
\text { Kelas }\end{array}$} & \multicolumn{2}{|c|}{$\begin{array}{c}\text { Tingkat Modal } \\
\text { Sosial Masyarakat }\end{array}$} \\
\hline & $\begin{array}{l}\text { Performansi } \\
\text { Dusung }\end{array}$ & & Kriteria & Nilai & & & Kelas & $\begin{array}{c}\text { Ukuran } \\
\text { (Total } \\
\text { Nilai) }\end{array}$ \\
\hline 1 & Produktivitas & $\begin{array}{l}\text { Pendapatan } \\
\text { Dusung/thn }\end{array}$ & $\begin{array}{l}<\text { Rp. } 15 \\
\text { Juta } \\
\text { Rp.15 Juta } \\
-25 \text { jt } \\
\text { Rp. >25 } \\
\text { Juta }\end{array}$ & $\begin{array}{l}1 \\
2 \\
3\end{array}$ & $\begin{array}{c}(30 * 1) \text { s.d } \\
(30 * 3) \\
30 \text { s.d } 90\end{array}$ & $\begin{array}{c}(90- \\
30) / 3= \\
20\end{array}$ & $\begin{array}{l}\text { Rendah } \\
\text { Sedang } \\
\text { Tinggu }\end{array}$ & $\begin{array}{l}30-50 \\
51-70 \\
71-90\end{array}$ \\
\hline 2 & Keberlanjutan & $\begin{array}{l}\text { Intensitas } \\
\text { Keg, }\end{array}$ & $\begin{array}{l}\text { Tidak } \\
\text { Pernah }\end{array}$ & $\begin{array}{l}1 \\
2\end{array}$ & $\begin{array}{c}(30 * 1) \text { s.d } \\
(30 * 3)\end{array}$ & $\begin{array}{c}(90- \\
30) / 3=\end{array}$ & $\begin{array}{l}\text { Rendah } \\
\text { Sedang }\end{array}$ & $\begin{array}{l}30-50 \\
51-70 \\
\end{array}$ \\
\hline
\end{tabular}

DOI: $10.30598 /$ jhppk.2020.4.2.150

ISSN ONLINE: 2621-8798 


\begin{tabular}{|c|c|c|c|c|c|c|c|c|}
\hline & & $\begin{array}{l}\text { Pemeliharaan } \\
\text { dusung }\end{array}$ & $\begin{array}{l}\text { Jarang } \\
\left(\text { kadang }^{2}\right) \\
\text { Sering }\end{array}$ & 3 & 30 s.d 90 & 20 & Tinggu & $71-90$ \\
\hline 3 & Keadilan & $\begin{array}{l}\text { Pihak lain } \\
\text { yang ikut } \\
\text { merasakan } \\
\text { manfaat } \\
\text { dusung }\end{array}$ & $\begin{array}{l}\text { Tidak ada } \\
\text { Pembeli } \\
\text { buahnya. } \\
\text { Banyak } \\
\text { pihak. }\end{array}$ & $\begin{array}{l}1 \\
2 \\
3\end{array}$ & $\begin{array}{c}(30 * 1) \text { s.d } \\
(30 * 3) \\
30 \text { s.d } 90\end{array}$ & $\begin{array}{c}(90- \\
30) / 3= \\
20\end{array}$ & $\begin{array}{l}\text { Rendah } \\
\text { Sedang } \\
\text { Tinggu }\end{array}$ & $\begin{array}{l}30-50 \\
51-70 \\
71-90\end{array}$ \\
\hline 4 & Efisiensi & $\begin{array}{l}\text { Persentase } \\
\text { biaya } \\
\text { produksi }\end{array}$ & $\begin{array}{l}>10 \% \\
5 \%-10 \% \\
<5 \%\end{array}$ & $\begin{array}{l}1 \\
2 \\
3\end{array}$ & $\begin{array}{c}(30 * 1) \text { s.d } \\
(30 * 3) \\
30 \text { s.d } 90\end{array}$ & $\begin{array}{c}(90- \\
30) / 3= \\
20\end{array}$ & $\begin{array}{l}\text { Rendah } \\
\text { Sedang } \\
\text { Tinggu }\end{array}$ & $\begin{array}{l}30-50 \\
51-70 \\
71-90\end{array}$ \\
\hline 5 & $\begin{array}{l}\text { Performansi } \\
\text { dusung }\end{array}$ & $\begin{array}{l}5 \text { Parameter } \\
\text { diatas }\end{array}$ & & & $\begin{array}{c}(30 * 4 * 1) \text { s.d } \\
(30 * 4 * 3) \\
150 \text { s.d } 450\end{array}$ & $\begin{array}{l}(360- \\
120) / 3 \\
=80\end{array}$ & $\begin{array}{l}\text { Buruk } \\
\text { Sedang } \\
\text { Baik }\end{array}$ & $\begin{array}{c}120- \\
200 \\
201- \\
280 \\
281- \\
360\end{array}$ \\
\hline
\end{tabular}

Analisis Pengaruh Modal Sosial dan

Performansi Dusung

Analisis regresi berganda merupakan metode statistika yang digunakan untuk menentukan kemungkinan bentuk hubungan antara variabel dependent dan beberapa variabel independent. Analisis regresi berganda juga dilakukan penilaian kebaikan model berdasarkan nilai koefisien determinasi. Uji signifikansi koefisien determinasi dilakukan dengan melihat nilai $\mathrm{F}$ hitung pada tabel ANOVA. Hipotesis yang digunakan untuk menguji koefisien determinasi adalah:

\section{HASIL DAN PEMBAHASAN}

Modal sosial kognitif masyarakat desa Murnaten dalam pengelolaan dusung meliputi kepercayaan (trust), kerjasama (cooperation), dan solidaritas (solidarity) warga komunitas dusung didasari oleh norma, nilai, sikap, dan keyakinan yang diorientasikan dalam bentuk tindakan (action) sehingga memunculkan dan menguatkan saling ketergantungan positif dari fungsi manfaat dan mendukung tindakan kolektif yang saling menguntungkan dalam pengelolaan dusung.
Ho: kontribusi gabungan dari variabel independent tidak signifikan

Ha: kontribusi gabungan variabel independent signifikan terhadap variabel dependent

Uji $F$ digunakan untuk menguji hipotesis. Jika F hitung lebih besar daripada F tabel, maka keputusan yang diambil adalah menolak Ho, sedangkan jika sebaliknya, menerima Ho. Koefisien determinasi yang digunakan analisis regresi berganda adalah koefisien determinasi yang disesuaikan (adjusted $\mathrm{R}$ square).

\section{Kepercayaan (Trust)}

Tingkat kepercayaan masyarakat desa Murnaten dalam pengelola dusung dilihat dari beberapa aspek antara lain: tingkat kepercayaan masyarakat terhadap pengetahuan masyarakat lain tentang adanya manfaat dusung; tingkat kepercayaan masyarakat terhadap pengetahuan masyarakat yang lain tentang fungsi aturan-aturan yang ada dalam mendukung pengelolaan dusung; tingkat kepercayaan masyarakat terhadap kemampuan kerjasama dan hubungan sosial seluruh masyarakat untuk mengelola dusung. 
Tingkat kepercayaan mengenai pengetahuan masyarakat tentang manfaat dusung $80 \%$ menyatakan ragu-ragu, diikuti percaya dan tidak percaya masing-masing $10 \%$. Pengetahuan warga akan fungsi aturan formal $77 \%$ ragu-ragu, percaya $17 \%$ dan tidak percaya $7 \%$. Pengetahuan warga akan fungsi aturan tidak tertulis yakni percaya $70 \%$, ragu-ragu $20 \%$ dan tidak percaya $10 \%$. Kemampuan warga melestarikan dusung yakni percaya $70 \%$, ragu-ragu $30 \%$, dan tidak percaya $0 \%$; sementara kemampuan kerjasama warga yakni percaya $53 \%$, raguragu $47 \%$ dan tidak percaya $0 \%$. Pengetahuan warga akan fungsi hubungan sosial yaitu percaya $57 \%$, diikuti ragu-ragu $37 \%$ dan tidak percaya $7 \%$. Terakhir kesediaan warga untuk menguatkan hubungan sosial yaitu percaya $60 \%$, ragu-ragu $40,0 \%$ dan tidak percaya $0 \%$ sebagaimana disajikan pada Tabel 3.

Tabel 3. Distribusi responden menurut tingkat kepercayaan

\begin{tabular}{lccc}
\hline & \multicolumn{3}{c}{ Tingkat Kepercayaan (\%) } \\
\cline { 2 - 4 } Kepercayaan Responsen & Tidak Percaya & Ragu-ragu & Percaya \\
\hline - Pengetahuan warga akan manfaat Dusung & 10 & 80 & 10 \\
- Pengetahuan warga akan fungsi aturan formal & 7 & 77 & 17 \\
- Pengetahuan warga akan fungsi aturan tidak tertulis & 10 & 20 & 70 \\
- Kemampuan warga melestarikan dusung & 0 & 30 & 70 \\
- Kemampuan kerjasama warga & 0 & 47 & 53 \\
- Pengetahuan warga akan fungsi hubungan sosial & 7 & 37 & 57 \\
- Kesediaan warga untuk menguatkan hubungan sosial & 0 & 40 & 60 \\
\hline
\end{tabular}

Sumber : Olah data primer, 2019

Tabel 3 menunjukkan bahwa tingkat kepercayaan masyarakat terkait manfaat dusung, fungsi aturan formal cenderung bersifat ragu-ragu. Sementara pengetahuan warga akan fungsi aturan tidak tertulis, kemampuan melestarikan dusung, fungsi hubungan sosial dan penguatan hubungan sosial relatif dipercaya masyarakat. Hasil ini terlihat dari persentase tanggapan responden cenderung tanggapannya ragu-ragu dan percaya. Masyarakat pengelola dusung di desa Murnaten rata-rata memiliki pengetahuan tentang manfaat dusung dan bahkan seluruh masyarakat percaya bahwa masyarakat mengetahui bahwa dusung memberikan manfaat yang besar kepada kehidupan masyarakat. Kepercayaan masyarakat terkait pengetahuan dan kemampuan hubungan sosial relatif baik.

Manfaat yang dirasakan oleh masyarakat terhadap keberadaan dusung mencakup aspek ekologi, ekonomi, dan sosial budaya. Secara ekologi, keberadaan dusung sangat berperan terhadap kelestarian hutan sebagai penyangga kehidupan, seperti pencegahan banjir, erosi, longsor, dan kekeringan, serta mencegah dari berbagai bencana alam lainnya. Secara ekonomi, masyarakat merasakan manfaat yang cukup besar dari hasil panen dusung yang mampu memberikan kontribusi yang penting terhadap pendapatan masyarakat. Adapun secara sosial budaya, keberadaan dusung dirasakan oleh masyarakat sebagai sarana untuk dapat mempererat kerjasama, solidaritas, kekeluargaan dan hubungan persaudaraan antar sesama.

Masyarakat juga percaya bahwa aturan-aturan yang ada, terutama aturan tertulis dan formal (peraturan perundangundangan) baik UU No. 41 Tahun 1999 Tentang Kehutanan, Peraturan Menteri Lingkungan Hidup dan Kehutanan Nomor P.83/Menlhk/Setjen/Kum.1/10/2016 tentang 
Perhutanan Sosial atau Peraturan Menteri Lingkungan Hidup dan Kehutanan Nomor P.21/Menlhk/Setjen/ Kum.1/4/2019 tentang Hutan Adat dan Hutan Hak, hanya sebagian kecil masyarakat yang percaya bahwa mereka tahu dan memahami aturan-aturan tertulis yang ada efektif dapat menjaga kelestarian dan keberlangsungan pengelolaan hutan. Pengetahuan warga terkait aturan-aturan dan nilai-nilai yang tidak tertulis (norma-norma) diyakini sebagian besar masyarakat tergolong tinggi.

Tingkat kepercayaan masyarakat terhadap pengetahuan masyarakat tentang fungsi aturan tidak tertulis (norma-norma) untuk mengelola dusung secara lestari lebih tinggi daripada kepercayaan terhadap pengetahuan masyarakat tentang aturan tertulis dan formal (peraturan perundangundangan). Hal ini karena aturan tidak tertulis sudah berlaku secara turun temurun dan terinternalisasi dalam adat atau kebiasaan masyarakat. Sedangkan aturan tertulis dan formal disusun oleh pemerintah dan belum terinternalisasi sebagai norma-norma yang diakui, dipatuhi, dan dijadikan pedoman dalam mengelola dusung. Bahkan sebagian masyarakat tidak pernah mendengar atau mengetahui aturan formal pemerintah dalam pengelolaan hutan dan lahan. Keberadaan aturan formal juga belum terbukti secara signifikan dapat berfungsi mengelola dan melestarikan dusung dengan baik. Aturan tidak tertulis (norma-norma) yang berlaku pada masyarakat di desa Murnaten antara lain: berupa cara (usage), kebiasaan (folkways), dan tata kelakuan (mores) yang merupakan kearifan lokalyang sudah berlaku secara turun temurun dan terinternalisasi dalam masyarakat.

Norma-norma (norms) berupa aturanaturan adat yang merupakan kearifan lokal dan berlaku dalam pengelolaan dusung diantaranya adalah sebagai berikut:

a. Tanaman gadihu atau puring adalah tanda batas hak kepemilikan lahan (dusung);

b. Di dalam dusung dibuat Walang/Nabane (pondok kecil untuk tempat beristirahat saat pemeliharaan atau kegiatan pengawasan tanaman);

c. Dalam pemanenan kelapa dibuat rumah asar kopra (tungku beratap untuk mengasap kopra)

d. Melibatkan tetangga/masyarakat yang tidak memiliki dusung bahkan masyarakat dari luar desa sebagai tenaga kerja dalam memanen hasil dusung terutama cengkih.

e. Memanen cengkih menggunakan tali dan bakul yang terbuat dari karung.

f. Memetik buah langsat dan pala dengan tongkat atau lalohar (alat pemetik buah terbuat dari bambu)

g. Memanen buah durian dengan cara menunggu buahnya jatuh.

h. Membuat rumah kebun yang disebut "walang" yang berfungsi sebagai tembat berteduh saat musim panen durian.

i. Pengangkutan buah atau hasil umbiumbian dari dusung ke rumah dengan menggunakan "hahalang";

j. Penjualan hasil panen buah langsung dari petani ke pembeli didalam dusung.

k. Tidak boleh menjual dusung pusaka dan dusung dati;

Norma-norma (norms) yang berlaku merupakan aturan-aturan adat berupa cara (usage), kebiasaan (folkways), dan tata kelakuan (mores) dalam pengelolaan dusung, sejak pengelolaan lahan, budidaya/pemeliharaan, pemanenan, hingga pemasaran hasil dusung. Aturan-aturan adat (norma-norma) tersebut meskipun tidak tertulis tetapi telah berlaku secara turun temurun dan terinternalisasi dalam masyarakat sebagai norma-norma yang diakui, dipatuhi, 
dan dijadikan pedoman dalam berinteraksi antar masyarakat sampai sekarang.

Kepatuhan seseorang terhadap aturan dapat diperlemah atau dikuatkan oleh kepatuhan orang lain terhadap aturan tersebut, sehingga penting pula untuk meninjau tingkat kepercayaan masyarakat terhadap kepatuhan masyarakat lain dalam melaksanakan aturan. Pada masyarakat pengelola dusung, sebagian besar percaya bahwa anggota komunitas yang lain dapat mematuhi aturan dan mampu menjaga kelestarian dusung dan hanya sebagian kecil yang ragu-ragu. Tingkat kepercayaan masyarakat bahwa anggota komunitas yang lain dapat mematuhi aturan dan mampu menjaga kelestarian dusung diperkuat oleh tingkat kepercayaannya bahwa masyarakat dusung dapat bekerjasama dalam menjaga kelestarian dusung.

\section{Kerjasama (Cooperation)}

Distribusi responden menurut tingkat kerjasama dalam kegiatan lingkungan dan pengelolaan dusung menunjukkan bahwa masyarakat sering terlibat kegiatan lingkungan sebesar $63 \%$, jarang terlibat $27 \%$
Tingkat kepercayaan (trust) antar sesama masyarakat dusung di desa Murnaten tergolong tinggi, hal ini karena dilandasi oleh norma-norma (norms), nilai-nilai (values), sikap (attitudes) dan keyakinan (beliefs) yang bersumber dari nilai-nilai ajaran agama Kristen Protestan yang mereka anut. Hal ini telah berlangsung secara turun temurun serta terinternalisasi dalam masyarakat sebagai norma-norma yang diakui, dipatuhi, dan dijadikan pedoman dalam berinteraksi baik terhadap sesama maupun terhadap lingkungan. Selain itu, adanya hubungan kekeluargaan berupa ikatan darah (marga) pada sebagian besar masyarakat dan mereka saling mengenal serta berhubungan dengan baik satu sama lain, semakin memperkuat ikatan kekeluargaan di antara mereka sehingga menjadi faktor pendukung tingkat kepercayaan (trust) yang tinggi di antara masyarakat.

dan tidak pernah 10\%; sementara masyarakat yang sering mengikuti kegiatan pengelolaan dusung sebesar $60,0 \%$, jarang $20 \%$ dan tidak pernah terlibat $20 \%$ sebagaimana disajikan pada Tabel 4.

Tabel 4. Distribusi Responden Menurut Tingkat Kerjasama

\begin{tabular}{lccc}
\hline & \multicolumn{3}{c}{ Tingkat Kerjasama (\%) } \\
\cline { 2 - 4 } Jenis Kerjasama & Tidak Pernah & Jarang & Sering \\
\hline Kegiatan Lingkungan & 10 & 27 & 63 \\
Kegiatan Pengelolaan Dusung & 20 & 20 & 60 \\
\hline
\end{tabular}

Sumber : Olah data primer, 2019

Tabel 4 menunjukkan bahwa tingkat kerjasama masyarakat pengelola dusung di desa Murnaten dalam berperan aktif dalam mengikuti kegiatan lingkungan dan/atau kemasyarakatan dan kegiatan pengelolaan dusung. Masyarakat desa Murnaten sering terlibat aktif dalam kegiatan gotong-royong dan kerja bakti seperti pembersihan lingkungan desa, gereja, perbaikan jalan, jembatan, dan lain-lain. Sebagian kecil masyarakat yang tidak pernah terlibat dalam kegiatan pengelolaan dusung dan kegiatan lingkungan sebagian kecil masyarakat dikarenakan keterbatasan kondisi sosial ekonomi serta cenderung sudah berusia lanjut dan memiliki status tidak memiliki suami (janda tua) serta tidak memiliki anggota 
keluarga yang telah terlibat mewakili dalam kegiatan gotong royong dan kerja bakti.

Tingkat kerjasama masyarakat pengelola dusung di desa Murnaten dalam kegiatan pengelolaan dusung cukup tinggi, sebagian besar masyarakat selalu melakukan kerjasama dengan anggota komunitas yang lain dalam kegiatan pengelolaan dusung. Sebagian kecil masyarakat dusung tergolong jarang melakukan kerjasama dengan anggota komunitas dusung yang lain dalam kegiatan pengelolaan, hal ini terjadi karena sebagian responden tersebut merasa mampu untuk melakukan kegiatan pengelolaan dusung tersebut secara sendiri (mandiri) sehingga hanya kadang-kadang saja melakukan kerjasama dengan petani yang lain (hanya kegiatan tertentu dan sewaktu-waktu saja).

Nilai-nilai (values) yang melekat pada masyarakat komunitas dusung yang mendukung terciptanya tingkat kerjasama (cooperation) yang tinggi antar sesame masyarakat pada dasarnya bersumber dari ajaran Kristen Protestan yang dianut oleh para masyarakatnya.Nilai-nilai (values) yang melekat kuat tersebut diantaranya adalah sebagai berikut.

a. Saling kerjasama dan tolong-menolong dalam kebaikan; Nilai-nilai luhur berupa kerjasama, gotong royong dan tolongmenolong merupakan karakter utama masyarakat turun-temurun. Masyarakat memegang teguh kebiasaan kerjasama, gotong royong/masohi dan tolongmenolong sesuai dengan perintah dalam ajaran agama Kristen Protestan yang mereka yakini. Masyarakat sadar bahwa dengan bekerjasama maka masing-masing

\section{Solidaritas (Solidarity)}

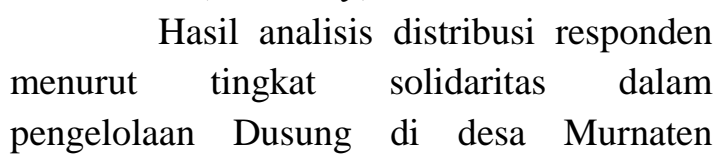

akan mendapat kemudahan dalam menyelesaikan setiap kegiatan atau permasalahan dalam kehidupan sosial mereka. Nilai-nilai kerjasama, gotong royong dan tolong-menolong untuk kebaikan ini terus dipertahankan masyarakat komunitas dusung, baik dalam kehidupan sehari-hari seperti pembersihan lingkungan, gereja, perbaikan jalan, jembatan, dll,

b. Mendahulukan kepentingan umum daripada kepentingan pribadi atau keluarga; Nilai-nilai kehidupan yang juga masih berlaku hingga sekarang pada masyarakat dalam pengelolaan dusung adalah berupa kewajiban untuk menjaga kepentingan umum (bersama) dan lebih mendahulukannya daripada kepentingan pribadi atau keluarga.

c. Hormat dan taat terhadap perintah/nasihat tokoh adat (tokoh masyarakat); Masyarakat dusung juga memiliki nilainilai yang berlaku sejak dahulu yaitu berupa kewajiban masyarakat untuk menghormati, patuh dan taat terhadap segala perintah/nasihat yang disampaikan oleh tua-tua adat (tokoh masyarakat). Apapun yang disampaikan oleh mereka selama tidak bertentangan dengan ajaran agama biasanya diikuti dan dilaksanakan oleh masyarakat. Kepatuhan masyarakat terhadap perintah/nasihat tua-tua adat ini semakin menguatkan hubungan sosial di antara sesama masyarakat yang terjalin dengan baik.

menunjukkan bahwa bentuk solidaritas masyarakat pelibatannya sebagai tenaga kerja/mitra sering $43 \%$, jarang terlibat $20 \%$, 
dan tidak pernah $37 \%$. Bentuk solidaritas dalam pembagian hasil panen kepada tetangga adalah sering $63 \%$, jarang $20 \%$, dan tidak pernah $17 \%$. Bentuk solidaritas dalam keikutsertaan dalam hajatan dan/ atau saat anggota masyarakat lain mengalami musibah sering $63 \%$, jarang $23 \%$, sering dan tidak pernah $13 \%$. Bentuk solidaritas masyarakat sebagaimana disajikan pada Tabel 5.

Tabel 5. Distribusi Responden Menurut Tingkat Solidaritas

\begin{tabular}{lccc}
\hline \multirow{2}{*}{ Bentuk Solidaritas } & \multicolumn{3}{c}{ Tingkat Solidaritas (\%) } \\
\cline { 2 - 4 } & Tidak Pernah & Jarang & Sering \\
\hline Pelibatan warga sebagai tenaga kerja/mitra & 37 & 20 & 43 \\
Membagikan hasil panen kepada tetangga & 17 & 20 & 63 \\
$\begin{array}{l}\text { Turut membantu warga yang hajatan/saat } \\
\text { mengalami musibah }\end{array}$ & 13 & 23 & 63 \\
\hline
\end{tabular}

Sumber :data primer, 2019

Terdapat tiga bentuk solidaritas masyarakat dalam pengelolaan hasil hutan dusung yaitu Pertama, solidaritas berupa pelibatan tetangga/masyarakat yang tidak memiliki dusung sebagai tenaga kerja/mitra dalam kegiatan pengelolaan dusung (pemeliharaan, pengawasan, pemanenan, dan pemasaran hasil dusung). Kedua, solidaritas berupa membagikan sebagian hasil panen dusung secara cuma-cuma kepada tetangga/masyarakat yang tidak memiliki dusung. Ketiga, solidaritas berupa membantu/menolong tetangga/ masyarakat yang sedang membangun rumah, melaksanakan hajatan (pesta perkawinan, Sidi Gereja, Baptis/sarane, syukuran, dll), ataupun yang sedang terkena musibah.

Tingkat solidaritas masyarakat pengelola dusung terhadap masyarakat luar maupun terhadap sesama masyarakat tergolong tinggi. Tingkat solidaritas masyarakat dusung di desa Murnaten terhadap masyarakat luar cukup tinggi dengan seringnya melibatkan tetangga/masyarakat yang tidak memiliki dusung sebagai tenaga kerja/mitra dalam kegiatan pengelolaan dusung. Masyarakat yang selalu melibatkan tetangga/masyarakat yang tidak memiliki dusung sebagai tenaga kerja/mitra dalam kegiatan pengelolaan dusung beralasan bahwa mereka ingin membantu memberikan tambahan penghasilan serta mempererat hubungan kekeluargaan dan mempererat persaudaraan.

Keterlibatan masyarakat relatif jarang atau tidak pernah melibatkan tetangga/ masyarakat yang tidak memiliki dusung sebagai tenaga kerja/mitra dalam kegiatan pengelolaan dusung lebih dikarenakan untuk penghematan biaya produksi karena tenaga kerja yang berasal dari anggota keluarga mereka sendiri dirasa cukup untuk mengelola dusung tersebut, dimana rata-rata mereka memiliki jumlah anggota keluarga lebih dari tiga orang. Tetangga/masyarakat yang tidak memiliki dusung umumnya dipekerjakan dalam kegiatan pemeliharaan dan pemanenan buah, bahkan jika masyarakat yang tidakmemiliki dusung tersebut memiliki modal yang cukup maka mereka akan dijadikan mitra sebagai pedagang perantara. Pemilik dusung sebenarnya dapat saja tidak menggunakan tenaga kerja tambahan dalam kegiatan pemeliharaan tanaman tetapi hal tersebut tetap dilakukan karena didorong oleh keinginan untuk berbagi rejeki serta 
mempererat hubungan kekeluargaan sebagai wujud solidaritas sebagai sesama masyarakat.

Solidaritas masyarakat komunitas pemilik dusung kepada masyarakat lainnya (baik sesama pemilik dusung maupun bukan) dalam kehidupan sehari-hari juga tinggi. Sebagian besar masyarakat saling membantu tetangga yang sedang membangun rumah, melaksanakan hajatan (pesta perkawinan, Sidi, baptis, dll), atau yang sedang terkena musibah, dan hanya sebagian kecil masyarakat yang jarang/kadang-kadang melakukan dilandasi oleh rasa empati, belas kasihan, serta adanya keyakinan bahwa berbuat baik atau menolong orang lain dengan penuh ketulusan, maka suatu saat senantiasa mendapat pertolongan dari Tuhan Yang Maha Kuasa.

Tingkat solidaritas (solidarity) antar sesama masyarakat pemilik dusung tergolong tinggi, hal ini karena dilandasi oleh normanorma (norms), nilai-nilai (values), sikap (attitudes) dan keyakinan (beliefs) yang melekat kuat pada setiap individu masyarakat tersebut dan sudah berlaku secara turun temurun serta terinternalisasi dalam masyarakat. Nilai-nilai (values) yang melekat pada masyarakat mendukung terciptanya tingkat solidaritas yang tinggi antar sesama masyarakat tersebut pada dasarnya juga dipengaruhi oleh ajaran agama Kristen Protestan yang dianut oleh para masyarakatnya.

Hasil pengukuran tingkat modal sosial kognitif dalam pengelolaan hasil hutan dusung di Desa Murnaten disajikan pada Tabel 6. Hasil perolehan total nilai modal sosial kognitif (kepercayaan, kerjasama, dan solidaritas) yang terdapat dalam masyarakat Desa Murnaten sebesar 870 termasuk dalam kategori tinggi. Modal sosial kognitif yang tinggi menunjukkan hasil proses tingkat kepercayaan, kerjasama dan solidaritas yang tinggi dari masyarakat Murnaten. Modal sosial kognitif yang tinggi sangat diperkuat oleh budaya, ideologi, norma, nilai, sikap dan keyakinan diantara masyarakat, terutama terkait juga dengan kejujuran, ketulusan, sikap empati, belas kasihan, kepedulian, tolong menolong, sifat tanpa pamrih, dan kesetiakwanan sosial, sehingga mewujudkan pengelolaan dusung secara lestari dan berkelanjutan

Tabel 6. Tingkat Modal sosial kognitif dalam pengelolaan Dusung

\begin{tabular}{llcc}
\hline No. & \multicolumn{1}{c}{ Unsur Modal Sosial } & Total Nilai & Kategori \\
\hline \multicolumn{2}{l}{ Modal Sosial Kognitif } & & \\
1 & Kepercayaan & 511 & Tinggi \\
2 & Kerjasama & 148 & Tinggi \\
3 & Solidaritas & 211 & Tinggi \\
\hline & & 870 & Tinggi \\
\hline & Modal Sosial & 1044 & Sedang \\
\hline
\end{tabular}

Sumber : data primer, 2019

Unsur-unsur modal sosial kognitif pada Tabel 6 menunjukkan total nilai modal sosial yang tinggi. Modal sosial kognitif memiliki keeratan hubungan sangat tinggi, saling mempengaruhi satu dengan lainnya. Modal sosial kognitif mempengaruhi perilaku 
sampai dengan mekanisme terbentuknya harapan dan/atau ekspektasi masyarakat yang pada akhirnya modal sosial kognitif lebih menentukan nilai-nilai bersama, norma dan harapan sebagai bagian dari perwujudan sikap dan pola perilaku masyarakat

Modal sosial kognitif dalam pengelolaan dusung pada Desa Murnaten

\section{Pengaruh Modal Sosial Kognitif terhadap Performansi Dusung}

Hasil analisis regresi berganda pengaruh modal sosial kognitif (kepercayaan, kerjasama dan solidaritas) terhadap performansi dusung (produktivitas, efisiensi, keberlanjutan dan keadilan disajikan pada Tabel 7 yakni hasil analisis kofisien telah mendukung terwujudnya performansi dusung yang tinggi. Hal ini dicirikan dengan nilai produktivitas yang tinggi, penggunaan sumberdaya yang efisien, keberlanjutan dan keadilan dalam pemanfaatan hasil hutan secara lestari dan optimal

determinansi menunjukkan bahwa adjusted $\mathrm{R}^{2}$ sebesar 0,771, yang berarti bahwa parameter modal sosial kognitif dan struktural terhadap performansi dusung memiliki pengaruh sebesar $77,1 \%$, dan $22,9 \%$ dipengaruhi oleh faktor diluar modal sosial kognitif (kepercayaan, kerjasama dan solidaritas).

Tabel 7. Model regresi pengaruh modal sosial kognitif terhadap performansi dusung

\begin{tabular}{cccccc}
\hline Model & $\mathrm{R}$ & R Square & $\begin{array}{c}\text { Adjusted } \mathrm{R} \\
\text { Square }\end{array}$ & $\begin{array}{c}\text { Std. Error of the } \\
\text { Estimate }\end{array}$ & Durbin-Watson \\
\hline 1 & $0,896^{\mathrm{a}}$ & 0,802 & 0,771 & 0,290 & 2,642 \\
\hline
\end{tabular}

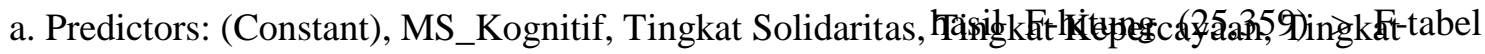
kerjasama

$(2,759)$ pada signifikan $0,000<0,01$ dan

b. Dependent Variable: Performansi Dusung

0,05 . Hasil ini menunjukkan bahwa modal

Tabel 8 menunjukkan bahwa sosial kognitif (kepercayaan, kerjasama dan solidaritas) memiliki pengaruh secara modal sosial kognitif (kepercayaan, kerjasama dan solidaritas) terhadap performansi dusung (produktivitas, efisiensi, keberlanjutan dan keadilan) memiliki pengaruh yang signifikan dengan signifikan terhadap performansi dusung (produktivitas, efisiensi, keberlanjutan dan keadilan) pada taraf kepercayaan 0,01 dan 0,05 .

Tabel 8. Hasil analisis ANOVA modal sosial terhadap performansi dusung

\begin{tabular}{lccccc}
\hline \multicolumn{1}{c}{ Model } & Sum of Squares & df & Mean Square & F & Sig. \\
\hline Regression & 8,558 & 4 & 2,139 & 25,359 & $0,000^{\text {a }}$ \\
\hline Residual & 2,109 & 25 & 0,084 & & \\
\hline Total & 10,667 & 29 & & & \\
\hline
\end{tabular}


a. Predictors: (Constant), MS_Kognitif,

b. Dependent Variable: Performansi

Tingkat Solidaritas, Tingkat Kepercayaan,

Dusung

Tingkat kerjasama

Tabel 9. Hasil uji parsial modal sosial kognitif terhadap performansi dusung

\begin{tabular}{|c|c|c|c|c|c|c|c|}
\hline \multirow[b]{2}{*}{ Model } & \multicolumn{2}{|c|}{$\begin{array}{l}\text { Unstandardized } \\
\text { Coefficients }\end{array}$} & \multirow{2}{*}{$\begin{array}{c}\begin{array}{c}\text { Standardized } \\
\text { Coefficients }\end{array} \\
\text { Beta }\end{array}$} & \multirow[b]{2}{*}{$\mathrm{t}$} & \multirow[b]{2}{*}{ Sig. } & \multicolumn{2}{|c|}{$\begin{array}{l}\text { Collinearity } \\
\text { Statistics }\end{array}$} \\
\hline & $\mathrm{B}$ & Std. Error & & & & Tolerance & VIF \\
\hline (Constant) & $-0,634$ & 0,304 & & $-20,085$ & 0,047 & & \\
\hline Tingkat Kepercayaan & 0,193 & 0,122 & 0,181 & 10,575 & 0,028 & 0,596 & 10,677 \\
\hline Tingkat kerjasama & 0,260 & 0,149 & 0,210 & 10,748 & 0,039 & 0,549 & 10,822 \\
\hline Tingkat Solidaritas & 0,341 & 0,155 & 0,253 & 20,203 & 0,037 & 0,600 & 10,666 \\
\hline MS_Kognitif & 0,586 & 0,112 & 0,537 & 50,248 & 0,000 & 0,755 & 10,325 \\
\hline
\end{tabular}

a. Dependent Variable: Performansi Dusung

Tabel 9 hasil uji parsial (uji-t) modal sosial kognitif (kepercayaan, kerjasama dan solidaritas) memiliki pengaruh signifikan terhadap performansi dusung (produktivitas, efisiensi, keberlanjutan dan keadilan). Tingkat kepercayaan, kerjasama dan solidaritas memiliki pengaruh signifikan terhadap performansi dusung secara uji

\section{KESIMPULAN}

Hasil analisis regresi berganda pengaruh modal sosial kognitif (kepercayaan, kerjasama dan solidaritas) terhadap performansi dusung (produktivitas, efisiensi, keberlanjutan dan keadilan menunjukkan hasil kofisien determinansi adjusted $\mathrm{R}^{2}$ sebesar 0,771, yang berarti bahwa modal sosial kognitif terhadap performansi dusung memiliki pengaruh sebesar $77,1 \%$, dan $22,9 \%$ dipengaruhi oleh faktor di luar modal sosial kognitif (kepercayaan, kerjasama dan solidaritas). Hasil F-hitung $(25,359)>$ F- parsial dengan nilai t-hitung secara berturutturut 10,$575 ; 10,748 ; 20,203$; dan 50,248 > ttabel $(2,057)$ dan signifikansi 0,$028 ; 0,039$; 0,037 , dan 0,000 lebih besar dari 0,05. Hasil uji $\mathrm{t}$ secara parsial menunjukkan bahwa modal sosial kognitif berpengaruh signifikan terhadap performansi dusung.

tabel $(2,759)$ pada signifikan $0,000<0,01$ dan 0,05 , yang berarti bahwa modal sosial kognitif (kepercayaan, kerjasama dan solidaritas) memiliki pengaruh signifikan secara simultanterhadap performansi dusung (produktivitas, efisiensi, keberlanjutan dan keadilan) pada taraf kepercayaan 0,01 dan 0,05 . Hasil uji parsial menunjukkan nilai $t-$ hitung secara parsial menunjukkan bahwa modal sosial kognitif berpengaruh signifikan terhadap performansi dusung. 


\section{DAFTAR PUSTAKA}

Ajawaila, JW; 1996.Sistem Sosial Budaya Agroforestry Dusung. Lokakarya Peran Dusung Terhadap Pelestarian Lingkungan. Kerjasama WIPTEKCIDA,Ambon

Coleman JS. 1988. Social Capital in The Creation of Human Capital. American Journal of Sociology. Volume 94.

Damsar. 2009. Pengantar Sosiologi Ekonomi. Jakarta: Prenada Media Group.

Irawan P.2007. Penelitian Kualitatif dan Kuantitatif untuk ilmu-ilmu social. Departemen Ilmu Administrasi. Fakultas Ilmu Sosial dan ilmu Politik. Depok: Universitas Indonesia.

Irwanto, 2014. Buah-Buahan Hasil Dusung.http://www.irwantoshut.com/f ruit dusun_agroforestry.html

Irwanto, 2015.Sistem-Sistem Agroforestry Tradisional. http://pengertiandefinisi.blockspot.com/2012/03/sistem -sistem-agroforestry-tradisional.html

Maruapey, A. 2013. Analisis Black Box SIstem Dusung (Agroforestry di Maluku. Jurnal Agroforestry VIII Nomor 4 Desember 2013. Hal 241247.

Oszaer, R; 2015.materi kuliah Perhutanan Sosial. Pasca Sarjana Manajemen Hutan. Univeristas Pattimura Ambon.

Putnam RD. 1993. The prosperous community social capital and public life.The American Prospect.

Silaya, Th. 2004. Kearifan Masyarakat Lokal dalam Pengelolaan Sumber Daya Hutan dan Lingkungan di Kecamatan
Taniwel Kabupaten Seram Bagian Barat. Thesis Program Studi Ilmu Kehutanan, Universitas Gajah Mada, Yogyakarta.

Silaya, Th. 2008. Hak Ulyat Masyarakat Dalam Pengelolaan Uumberdaya Hutan Di Desa Walakone Kecamatan Taniwel Kabupaten Seram Bagian Barat. Jurnal Agroforestri Volume III.

Singarinbun M,Effendi S 2008. Metode Penelitian Survey (Edisi Revisi). Jakarta: LP3ES.

Suharjito D, Khan A, Djatmiko WA, Sirait MT, Evelyna S. 2000. Karakteristik Pengelolaan Hutan Berbasiskan Masyarakat. Kerjasama FKKM-Ford Foundation. Yogyakarta: Aditya Media.

Suharjito D, dan Saputro GE. 2008. Modal Sosial dalam Pengelolaan Sumberdaya Hutan pada Masyarakat Kasepuhan, Banten Kidul. Jurnal Penelitian Sosial dan Ekonomi Kehutanan Vol 5 No 4: 317-335. Bogor: Pusat Penelitian Sosial Ekonomi dan Kebijakan Kehutanan Badan Penelitian dan Pengembangan Kehutanan Kementerian Kehutanan.

Suharjito D. 2002. Kebun-Talun: Strategi Adaptasi Sosial Kultural dan Ekologi Masyarakat Pertanian Lahan Kering di Desa Buniwangi, Sukabumi, Jawa Barat. Disertasi Program Studi Antropologi Universitas Indonesia. Depok: Tidak Diterbitkan.

Uphoff N. 2000. Understanding Social Capital: Learning from the Analysis and Experience of Participation. In Dasgupta P and Serageldin I (eds). 2000. 
DOI: 10.30598/jhppk.2020.4.2.150

ISSN ONLINE: 2621-8798

Page 164 